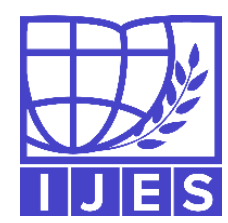

Article History Received: 09.11.2021 Accepted: 10.12.2021 Published: 25.12.2021
International Journal of Education and Science print ISSN: 2618-0553; online ISSN: 2618-0561; DOI: 10.26697/ijes Journal Website: https://ijes.world

SOCIAL AND BEHAVIORAL SCIENCES

Education ORIGINAL RESEARCH

\section{Predictors of Teacher's Engagement of Higher Education: An Exploratory Study}

\section{Reshmi MANNA $^{1^{*}}$ (1), Ankit SINGH ${ }^{2}$ (1)}

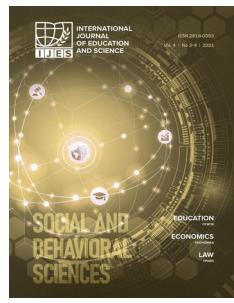

\author{
${ }^{1}$ HR Knowledge Lab, India \\ ${ }^{2}$ NTPC School of Business, India \\ * Corresponding Author's Email: dr.reshmi.manna@gmail.com
}

Предиктори спільності викладачів вищої освіти: попереднє дослідження Манна P. ${ }^{1}$, Сінгх А. ${ }^{2}$

${ }^{1}$ Лабораторія HR знань, Індія

${ }^{2}$ Школа бізнесу NTPC, Індія

\author{
Предикторы сообщности преподавателей высшего образования: \\ предварительное исследование \\ Манна P. ${ }^{1}$, Сингх A. ${ }^{2}$ \\ ${ }^{1}$ Лаборатория НR знаний, Индия \\ ${ }^{2}$ Школа бизнеса NTPC, Индия
}

\begin{abstract}
Background: The study explores the personal characteristic and organisational environment as predictors of engagement. The teacher engagement has job engagement, organisation engagement and research engagement as the second-order construct.

Purpose: To explore the different dependent and independent variables contributing towards the construct of teacher engagement and its predictors; to develop an instrument to measure levels of teacher engagement; to predict the factors contributing to teacher engagement to enable institution management to graft job and organisation environment.

Materials and Methods: The research aimed to develop an instrument to measure the level of engagement among teachers. The items of the tool were generated from the meta-analysis of the literature. This research was conducted at three educational institutes, and the samples were selected by the probability sampling method. To check sample adequacy KMO test was being conducted. Factors were explored through exploratory factor analysis, and predicting factors were linearly regressed.

Results: This study on teacher engagement in the Indian perspective indicated that pay, benefits, objectivity, career growth and interpersonal relation are hygiene factors. However, work ethics and job content are the motivational factors in making teachers engage with their job or organisation.

Conclusions: This research emphasised better job design to encourage the teacher and utilise their skills and competencies to the maximum. Focusing on the motivational factors improved work quality and work-life balance as well.
\end{abstract}

Keywords: teacher engagement, personal characteristics, organisational environment.
DOI: https://doi.org/10.26697/ijes.2021.3.3
JEL: I20, I23
UDC: $378.126: 378.14$

Cite this article as: Manna, R., \& Singh, A. (2021). Predictors of teacher's engagement of higher education: An exploratory study. International Journal of Education and Science, 4(3-4), 33-39. https://doi.org/10.26697/ijes.2021.3.3

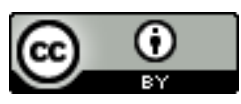
(C) 2021 Manna R., Singh A.

Published by Archives of International Journal of Education and Science

Open Access under a Creative Commons "Attribution" 4.0 Worldwide

\section{Introduction}

Teacher engagement has been identified as one of the most critical factors in the success and future of education (Huberman, 1993; Nias, 1981). It plays a vital role in teachers' work performance, reduces absenteeism, burnout and turnover, and influences students' achievement and attitude (Firestone, 1996; Graham, 1996; Lewis, 1990; Tsui \& Cheng, 1999). Crosswell and Elliott (2002) describe teacher engagement as 'caring', 'dedicated' and 'take the job seriously' from those who 'put their interests first. Some teachers find engagements as professional 
identities as they derive a lot of enjoyment from their job (Elliott \& Crosswell, 2001). The innovative potential of modern teacher is essential (Melnyk \& Pypenko, 2017). Teaching is a complex and demanding profession that requires a high level of engagement in work with both head and heart (Day, 2004; Elliott \& Crosswell, 2001; Fried, 1995; Nias, 1996). To quote from Barman and Roy's study (2011), “an engaged faculty will show a high degree of commitment and involvement in the profession. For him/her, teaching is more of commitment than compliance" (p. 143). The levels of engagement can be reflected through job engagement, organisation engagement and research engagement. The engagement for teaching cannot be considered 'luxury, a frill, or a quality possessed by few teachers; instead, a sense of passion is 'essential to all good teaching' (Day, 2004). Sustaining passion for teaching or job is intimately connected with teachers' engagement with employment, which relates to their sense of professional and organisational identity as organisational engagement. Recent research in this area makes this belief even more grounded (Melnyk \& Pypenko, 2020; Pypenko, Maslov, \& Melnyk, 2020).

The aim of the study. To explore the different dependent and independent variables contributing towards the construct of teacher engagement and its predictors; to develop an instrument to measure levels of teacher engagement; to predict the factors contributing to teacher engagement to enable institution management to graft job and organisation environment so that it will contribute to teacher development, institution development, and societal development at large.

The study will explore the personal characteristic and organisational environment as predictors of engagement. The second-order construct's unique aspect will have the locus of control (internal) and work ethics as the independent variable. The secondorder organisational environment has benefits, career opportunities, interpersonal relations, job content, objectivity, and pay as independent variables. The teacher engagement has job engagement, organisation engagement and research engagement as the secondorder construct. The research aims to construct an instrument to measure the predicting factors contributing to the higher level of engagement among under and post-graduate teachers. The study also will try to answer the research question "how universities and colleges should engage their faculties to enhance teaching effectiveness (job engagement), mutual loyalty (organisation engagement) and research productivity (research engagement)?”

\section{Materials and Methods}

The research aims to develop an instrument to measure the level of engagement among teachers. The items of the tool are generated from the meta-analysis of the literature. This research is an empirical exploratory pilot study to establish the principle variables of all the factors considered for the construct of the study. This research is conducted at three educational institutes of
Delhi, and the samples are selected by the probability sampling method after taking concern of the respective department. To check sample adequacy KMO test is being conducted. Factors are explored through exploratory factor analysis, and predicting factors are linearly regressed to check their variation affecting the dependent engagement variables.

\section{Results and Discussion}

All the 76 statements of the questionnaire were positively worded; hence reverse scoring is not required. Response for the statement is measured through a four-point Likert scale: Not at all true (0); somewhat true (1); largely true (2) and absolutely true (4). The summation of responses to all the assumed variables is the aggregate of an individual respondent's score. Initially, the questionnaire contains 76 statements; after exploratory factor analysis for data reduction through principal component analysis, the final 59 statements are tested for reliability with the help of Cronbach Alpha. Four items were deleted for job engagement; Cronbach's alpha tests the intercorrelations among items to estimate the internal consistency. The alpha values of the assumed 11 variables meet the conventional level of acceptance (alpha >0.60), indicating inter-correlations among tested items are maximised when all items measure the same construct, as shown in Table 1.

Cronbach's alpha indirectly indicates the degree to which a set of items measures a single uni-dimensional latent construct. With alpha score support, the convergent construct validity of the 11 variables are established through the degree of inter-correlation of the variables found through theoretical review claims is proved to be true in the subsequent analysis.

The KMO Measure of Sampling Adequacy value for a set of variables indicated in Table 1 fall in the range between 0.62 to 0.87 , which would be labelled as the range between 'mediocre' to 'meritorious'. Bartlett's Test of Sphericity is significant at 0.05 level, showing the validity and suitability of the responses collected to the problem addressed through this study. Bartlett's sphericity tests also indicate that the correlation matrix is an identity matrix; i.e. all diagonal elements are 1, and all off-diagonal features are 0, implying that all items/statements are uncorrelated.

Table 2 indicates the basic findings of the responses to the 11 variables are discriminating, as the mean percentage score ranges between $42.8 \%$ to $63.23 \%$ and is well spread around each mean score.

The response score is fairly high in terms of the level of engagement for the organisation (63.23\%) and research $(72.16 \%)$. The job engagement (49.26\%) scored below average, indicating the institutions should work towards policy design to increase teachers' engagement. The difference in engagement scores are statistically insignificant (NS) as $\mathrm{P}<0.05 \quad$ [Job Engagement $\mathrm{F}=0.78$, Sig=0.379 (NS); Organisation Engagement $\mathrm{F}=2.77$, Sig=0.099 (NS) and Research Engagement $\mathrm{F}=1.40$, Sig=0.238 (NS)] indicating no different in the levels of engagement between gender. 


\section{Table 1}

Summary of Exploratory Factor Analysis $(n=100)$

\begin{tabular}{|c|c|c|c|c|c|c|c|}
\hline $\begin{array}{l}\text { Serial } \\
\text { No. }\end{array}$ & Variable & $\begin{array}{l}\text { No. of } \\
\text { Items }\end{array}$ & $\begin{array}{l}\text { Score } \\
\text { Range }\end{array}$ & $\begin{array}{c}\text { KMO \& } \\
\text { Bartlett's Test }\end{array}$ & $\begin{array}{l}\text { Statement } \\
\text { Indicator }\end{array}$ & $\begin{array}{c}\text { Factor } \\
\text { Loading } 1\end{array}$ & $\begin{array}{c}\text { Cronbach } \\
\text { Alpha }\end{array}$ \\
\hline 1. & $\begin{array}{l}\text { Organisation } \\
\text { Engagement }\end{array}$ & 10 & $0-30$ & $0.88 *$ & $\begin{array}{c}\text { Q8 } \\
\text { Q19 } \\
\text { Q30 } \\
\text { Q41 } \\
\text { Q52 } \\
\text { Q58 } \\
\text { Q62 } \\
\text { Q67 } \\
\text { Q71 } \\
\text { Q75 }\end{array}$ & $\begin{array}{l}0.866 \\
0.757 \\
0.820 \\
0.705 \\
0.881 \\
0.909 \\
0.719 \\
0.655 \\
0.812 \\
0.864 \\
\end{array}$ & 0.937 \\
\hline 2. & Job Engagement & 6 & $0-18$ & $0.80 *$ & $\begin{array}{l}\text { Q14 } \\
\text { Q25 } \\
\text { Q56 } \\
\text { Q60 } \\
\text { Q65 } \\
\text { Q69 }\end{array}$ & $\begin{array}{l}0.672 \\
0.873 \\
0.796 \\
0.609 \\
0.589 \\
0.677 \\
\end{array}$ & 0.835 \\
\hline 3. & $\begin{array}{l}\text { Research } \\
\text { Engagement }\end{array}$ & 4 & $0-12$ & $0.62 *$ & $\begin{array}{l}\text { Q22 } \\
\text { Q44 } \\
\text { Q55 } \\
\text { Q65 }\end{array}$ & $\begin{array}{l}0.810 \\
0.645 \\
0.685 \\
0.595\end{array}$ & 0.631 \\
\hline 4. & $\begin{array}{l}\text { Locus of Control } \\
\text { (Internal) }\end{array}$ & 4 & $0-12$ & $0.76 *$ & $\begin{array}{l}\text { Q39 } \\
\text { Q59 } \\
\text { Q68 } \\
\text { Q76 }\end{array}$ & $\begin{array}{l}0.672 \\
0.524 \\
0.812 \\
0.720\end{array}$ & 0.729 \\
\hline 5. & Work Ethics & 5 & $0-15$ & $0.70 *$ & $\begin{array}{l}\text { Q54 } \\
\text { Q57 } \\
\text { Q61 } \\
\text { Q66 } \\
\text { Q70 }\end{array}$ & $\begin{array}{l}0.513 \\
0.710 \\
0.779 \\
0.611 \\
0.551 \\
\end{array}$ & 0.789 \\
\hline 6. & Benefit & 5 & $0-15$ & $0.81 *$ & $\begin{array}{c}\text { Q1 } \\
\text { Q12 } \\
\text { Q23 } \\
\text { Q34 } \\
\text { Q45 }\end{array}$ & $\begin{array}{l}0.862 \\
0.831 \\
0.878 \\
0.637 \\
0.654 \\
\end{array}$ & 0.826 \\
\hline 7. & Career Opportunity & 5 & $0-15$ & $0.87 *$ & $\begin{array}{c}\text { Q2 } \\
\text { Q13 } \\
\text { Q24 } \\
\text { Q35 } \\
\text { Q46 }\end{array}$ & $\begin{array}{l}0.892 \\
0.864 \\
0.890 \\
0.658 \\
0.888 \\
\end{array}$ & 0.896 \\
\hline 8. & $\begin{array}{l}\text { Interpersonal } \\
\text { Relations }\end{array}$ & 5 & $0-15$ & $0.85^{*}$ & $\begin{array}{c}\text { Q4 } \\
\text { Q15 } \\
\text { Q26 } \\
\text { Q37 } \\
\text { Q48 } \\
\end{array}$ & $\begin{array}{l}0.850 \\
0.837 \\
0.730 \\
0.897 \\
0.767 \\
\end{array}$ & 0.876 \\
\hline 9. & Job Content & 5 & $0-15$ & $0.77 *$ & $\begin{array}{c}\text { Q5 } \\
\text { Q16 } \\
\text { Q27 } \\
\text { Q38 } \\
\text { Q49 }\end{array}$ & $\begin{array}{l}0.787 \\
0.830 \\
0.765 \\
0.613 \\
0.669 \\
\end{array}$ & 0.780 \\
\hline 10. & Objectivity & 5 & $0-15$ & $0.82 *$ & $\begin{array}{c}\text { Q7 } \\
\text { Q18 } \\
\text { Q29 } \\
\text { Q40 } \\
\text { Q51 }\end{array}$ & $\begin{array}{l}0.817 \\
0.743 \\
0.808 \\
0.849 \\
0.835 \\
\end{array}$ & 0.869 \\
\hline 11. & Pay & 5 & $0-15$ & $0.83 *$ & $\begin{array}{c}\text { Q9 } \\
\text { Q20 } \\
\text { Q31 } \\
\text { Q42 } \\
\text { Q53 }\end{array}$ & $\begin{array}{l}0.854 \\
0.948 \\
0.897 \\
0.719 \\
0.732\end{array}$ & 0.889 \\
\hline
\end{tabular}


Table 2

Summary of Basic Findings $(n=100)$

\begin{tabular}{|c|c|c|c|c|}
\hline $\begin{array}{c}\text { Serial } \\
\text { No. }\end{array}$ & Variable & Mean & $\begin{array}{l}\text { Standard } \\
\text { Deviation }\end{array}$ & $\begin{array}{c}\text { Mean as } \\
\text { Percentage }\end{array}$ \\
\hline & Teacher Engagement & & & \\
\hline 1. & Organisation Engagement & 18.97 & 7.60 & 63.23 \\
\hline 2. & Research Engagement & 8.66 & 2.31 & 72.16 \\
\hline \multirow[t]{2}{*}{3.} & Job Engagement & 14.78 & 3.14 & 49.26 \\
\hline & Personal Attributes & & & \\
\hline 4. & Work Ethics & 12.52 & 2.57 & 83.46 \\
\hline \multirow[t]{2}{*}{5.} & Locus of Control (Internal) & 9.07 & 2.21 & 75.58 \\
\hline & Organisation Climate & & & \\
\hline 6. & Job Content & 9.97 & 3.17 & 66.46 \\
\hline 7. & Interpersonal_Relationship & 9.21 & 3.50 & 61.4 \\
\hline 8. & Objectivity & 7.70 & 4.03 & 51.33 \\
\hline 9. & Pay & 6.97 & 4.21 & 46.46 \\
\hline 10. & Career Opportunity & 6.68 & 4.25 & 44.53 \\
\hline 11. & Benefit & 6.42 & 3.91 & 42.8 \\
\hline
\end{tabular}

The score for two personal attributes is also found to be fairly high; positive work ethics (83.46) mean score is much higher than internal locus of control $(75.58 \%)$. The fairly high mean score in work ethics helps predict that the teachers from the northern region of India are more integrated, disciplined, and have a sense of responsibility toward their job. Teachers with a higher average internal locus of control believe that decisions and efforts guide rewards in life, so if one fails, it is due to one's lack of effort and understanding. The mean score of the organisational climate shows mixed results. The means score is listed in descending order in Table 2 indicates job content $(66.46 \%)$ and interpersonal relation $(61.4 \%)$ are above average. The respondents' teachers have clarity about their job content, and interpersonal relations between colleagues are well established. Objectivity $(51.33 \%)$ is averagely scored. Pay $(46.46 \%)$, career opportunity $(44.53 \%)$ and benefit $(42.8 \%)$ are scored below average. Therefore, the institutions' management should set a priority action plan to improve the organisation climate by reconsidering the pay, benefits, and career opportunities for the teachers in the northern region of India.

The study aims to identify the predictors of teacher engagement, which call for bivariate and multivariate analysis. The first step in that direction is $11 \times 11$ Pearson's inter-correlation matrix, as indicated in Table 3.

Table 3

Inter-Correlation Matrix of All 11 Variables Selected for Study $(n=100)$

\begin{tabular}{|c|c|c|c|c|c|c|c|c|c|c|c|}
\hline Variables & $1 \mathrm{JE}$ & $2 \mathrm{OE}$ & $3 R E$ & $4 \mathrm{~B}$ & $5 \mathrm{CO}$ & 6IR & 7JC & 80 & $9 \mathrm{P}$ & 10LOC & $11 \mathrm{WE}$ \\
\hline 1. Job Engagement (JE) & 1 & & & & & & & & & & \\
\hline $\begin{array}{l}\text { 2. Organisation Engagement } \\
\text { (OE) }\end{array}$ & 0.70 & 1 & & & & & & & & & \\
\hline $\begin{array}{l}\text { 3. Research Engagement } \\
\text { (RE) }\end{array}$ & 0.55 & 0.50 & 1 & & & & & & & & \\
\hline 4. Benefit (B) & 0.54 & 0.75 & 0.51 & 1 & & & & & & & \\
\hline 5. Career Opportunity (CO) & 0.59 & 0.81 & 0.48 & 0.87 & 1 & & & & & & \\
\hline $\begin{array}{l}\text { 6. Interpersonal Relationship } \\
\text { (IR) }\end{array}$ & 0.49 & 0.58 & 0.55 & 0.57 & 0.62 & 1 & & & & & \\
\hline 7. Job Content (JC) & 0.75 & 0.80 & 0.66 & 0.78 & 0.79 & 0.69 & 1 & & & & \\
\hline 8. Objectivity $(\mathrm{O})$ & 0.61 & 0.80 & 0.55 & 0.73 & 0.86 & 0.68 & 0.80 & 1 & & & \\
\hline 9. Pay $(\mathrm{P})$ & 0.60 & 0.78 & 0.51 & 0.88 & 0.85 & 0.55 & 0.73 & 0.73 & 1 & & \\
\hline 10. Locus of Control (LOC) & 0.67 & 0.53 & 0.51 & 0.47 & 0.50 & 0.36 & 0.59 & 0.47 & 0.43 & 1 & \\
\hline 11. Work Ethics (WE) & 0.73 & 0.65 & 0.49 & 0.51 & 0.54 & 0.33 & 0.62 & 0.53 & 0.50 & 0.79 & 1 \\
\hline
\end{tabular}

Note. Table is statistically significant $(\mathrm{p}<0.01)$.

The first two-column of Table 3 depicts that all eight independent variables are positively and significantly related to each dimension of teacher engagement at under-graduate and post-graduate levels. The high multi-collinearity of the data makes it necessary to perform multivariate analysis for the actual predictors of each dimension for teacher's engagement (indicated in Table 4). 


\section{Table 4}

Critical Predictors of Teacher Engagement

\begin{tabular}{|c|c|c|c|c|}
\hline $\begin{array}{l}\text { Serial } \\
\text { No. }\end{array}$ & Predictors & $\begin{array}{c}\text { Zero-order } \\
\text { Correlation (A) } \\
\end{array}$ & $\begin{array}{l}\text { Standardised Beta } \\
\text { Coefficients (B) }\end{array}$ & $\begin{array}{l}\text { Individual Contribution } \\
\text { (A) } \mathrm{x}(\mathrm{B})\end{array}$ \\
\hline 1. & Pay & $0.788 * * *$ & $0.318^{* * *}$ & 0.250 \\
\hline 2. & Objectivity & $0.801 * * *$ & $0.289 * * *$ & 0.231 \\
\hline 3. & Job Content & $0.805^{*}$ & $0.207^{*}$ & 0.166 \\
\hline 4. & Work Ethics & $0.656 * * *$ & $0.211 * * *$ & 0.138 \\
\hline \multicolumn{3}{|c|}{ Dependent Variable: Organisation Engagement } & Total $\mathrm{R}^{2}$ & 0.785 \\
\hline $\mathrm{R}=0.887$ & $\mathrm{R}^{2}=0.787$ & Adjusted $\mathrm{R}^{2}=0.778$ & Durbin-Watson 1.685 & $\mathrm{~F}=87.867(\mathrm{P}<0.001)$ \\
\hline 1. & Job Content & $0.759 * * *$ & $0.489 * * *$ & 0.371 \\
\hline 2. & Work Ethics & $0.739 * * *$ & $0.435 * * *$ & 0.321 \\
\hline \multicolumn{3}{|c|}{ Dependent Variable: Job Engagement } & Total $\mathrm{R}^{2}$ & 0.692 \\
\hline $\mathrm{R}=0.832$ & $\mathrm{R}^{2}=0.693$ & Adjusted $\mathrm{R}^{2}=0.431$ & Durbin-Watson 2.063 & $\mathrm{~F}=109.472(\mathrm{P}<0.001)$ \\
\hline 1. & Job Content & $0.661 * * *$ & $0.661 * * *$ & 0.436 \\
\hline \multicolumn{3}{|c|}{ Dependent Variable: Research Engagement } & Total $\mathrm{R}^{2}$ & 0.436 \\
\hline$R=0.661$ & $\mathrm{R}^{2}=0.436$ & Adjusted $\mathrm{R}^{2}=0.431$ & Durbin-Watson 2.069 & $\mathrm{~F}=75.873(\mathrm{P}<0.001)$ \\
\hline
\end{tabular}

Stepwise multiple regression analysis was carried out to identify a particular combination of independent variables or variables explaining the highest amount of variance $\left(\mathrm{R}^{2}\right)$ with all regression coefficients statistically significant at least 5 per cent that describe the particular dimension of engagement (refer to Table 4 for details). Organisation engagement has four predictors as pay; objectivity, job content and work ethic explain $78.5 \%$ of the variance. Pay and objectivity emerged as the dominant predictors as their individual contributions are $25 \%$ and $23.1 \%$, respectively. Job content contributes $37.1 \%$, and work ethics contributes $32.1 \%$ in the total $69.2 \%$ variance in job engagement. Both variables are equally responsible for the variation, with job content in a little higher position. Job content is the only predictor for research engagement and is accountable for $43.6 \%$ of the variance. The Durbin-Watson values of all three regression models lie approximately around value 2 , indicating no auto-correlation in the respondents.

\section{Conclusions}

This pilot study on teacher engagement in the Indian perspective indicate that pay, benefits, objectivity, career growth and interpersonal relation are hygiene factors; however, work ethics and job content are the motivational factors in making teachers engage with their job or organisation. This research somewhere implies the Two-Factor Theory of Herzberg (1966) that institutional management must stress upon guaranteeing the adequacy of the hygiene factors to avoid disengagement affecting the quality of education (subjecting to further research). Also, it is crucial to make sure that the work is stimulating and rewarding so that the teachers are motivated to work and perform more challenging and better. This research emphasises better job design to encourage the teacher and utilise their skills and competencies to the maximum. Focusing on the motivational factors will improve work quality and work-life balance as well.

\section{Funding Source}

This research received no specific grant from any funding agency in the public, commercial, or not-forprofit sectors.

\section{Conflicts of Interests}

The authors declare that there is no conflict of interests.

\section{References}

Barman, A., \& Saikat, R. (2011). Faculty engagement in higher educational institution - A proposed model. Revista Romaneasca Pentru Educatie Multidimensional (Romanian Journal for Multidimensional Education), 3(7), 43-164. https://revistaromaneasca.ro/wpcontent/uploads/2011/11/FacultyEngagement-in-Higher.pdf

Crosswell, L. (2003). The dimensions of teacher commitment: The different ways in which teachers conceptualise and practice their commitment. In S. Danby, J. Knight, \& E. McWilliam, (Eds.), Performing Educational Research: Theories, Methods and Practices (pp. 89-103). Post Pressed, Flaxton, Queensland. https://eprints.qut.edu.au/21505/

Elliott, B., \& Crosswell, L. (2001). Commitment to teaching: Australian perspectives on the interplays of the professional and the personal in teachers' lives. Paper presented at the International Symposium on Teacher Commitment at the European Conference on Educational Research, Lille, France. https://eprints.qut.edu.au/968/1/cro04237.pdf

Elliott, B., \& Crosswell, L. (2002). Teacher commitment and engagement: The dimensions of ideology and practice associated with teacher commitment and engagement within an Australian perspective. Paper presented at the Annual Conference of Australian Association for Research in Education, Brisbane.

https://www.aare.edu.au/data/publications/200 2/cro02522.pdf 
Firestone, W. A. (1996). Images of teaching and proposals for reform: A comparison of ideas from cognitive and organisational research. Educational Administration Quarterly, 32(2), 209-235. https://doi.org/10.1177/0013161X96032002003

Fried, R. L. (1995). The passionate teacher: A practical guide. Beacon Press. https://www.worldcat.org/title/passionateteacher-a-practical-guide/oclc/45729386

Graham, K. C. (1996). Running ahead enhancing teacher commitment. Journal of Physical Education, Recreation and Dance, 67(1), 4547.

https://doi.org/10.1080/07303084.1996.10607 182

Huberman, M. A. (1993). The lives of teachers. Teachers College Press. https://www.worldcat.org/title/lives-ofteachers/oclc/28586037

Herzberg, F. (1966). Work and the nature of man. World Publishing. https://www.worldcat.org/title/work-and-thenature-of-man/oclc/243610

Lewis, H. (1990). A question of values. Harper \& Row. https://openlibrary.org/works/OL4484752W/A _question_of_values

Melnyk, Y., \& Pypenko, I. (2017). Innovative potential of modern specialist: the essence and content.
In Yu. B. Melnyk (Ed.), Psychological and pedagogical problems of modern specialist formation (pp.9-16). ANAGRAM; KRPOCH. https://doi.org/10.26697/9789669726094.2017.9

Melnyk, Yu. B., \& Pypenko, I. S. (2020). How will blockchain technology change education future?! International Journal of Science Annals, 3(1), 5-6. https://doi.org/10.26697/ijsa.2020.1.1

Nias, J. (1981). Commitment and motivation in primary school teachers. Educational Review, 33(3),

$181-190$. https://doi.org/10.1080/0013191810330302

Nias, J. (1996), Thinking about felling: The emotion in teaching. Cambridge Journal of education, 26(3),

293-306. https://doi.org/10.1080/0305764960260301

Pypenko, I. S., Maslov, Yu. V., \& Melnyk, Yu. B. (2020). The impact of social distancing measures on higher education stakeholders. International Journal of Science Annals, 3(2), 9-14. https://doi.org/10.26697/ijsa.2020.2.2

Tsui, K. T., \& Cheng, Y.C. (1999). School organisational health and teacher commitment: A contingency study with multi-level analysis. Educational Research and Evaluation, 5(3), 249-268.

https://doi.org/10.1076/edre.5.3.249.3883

\begin{abstract}
Анотація
Bступ: У дослідженні розглядаються особистісні показники та організаційне середовище як предиктори залученості. Залученість викладача включає у собі залученість до роботи, залученість до організачії та залученість до дослідження як конструкт другого порядку.

Мета: Дослідити різні залежні та незалежні змінні, щзо впливають на побудову залученості викладачів та їх предиктори; розробити інструмент для вимірювання рівня залучення викладачів; спрогнозувати фактори, що сприяють залученню викладачів, щэоб надати можливість керівництву навчального закладу пов'язати роботу та організаиійне середовище.

Матеріали і Методи: Дослідження спрямоване на розробку інструментарію для вимірювання рівня залучення викладачів. Компоненти інструментарію створені з урахуванням мета-аналізу літератури. Це дослідження проводилося у трьох навчальних закладах, а зразки відібрано методом імовірнісної вибірки. Для перевірки адекватності вибірки проведено тест КМО. Чинники вивчалися за допомогою дослідницького факторного аналізу, а прогнозуючі чинники піддавалися лінійній регресії.

Результати: Це дослідження залученості викладачів показало, щуо оплата, пільги, об'єктивність, кар'єрне зростання та міжособистісні взаємовідносини є гігієнічними факторами для Індї. Тим не менш, трудова етика та зміст роботи є мотивуючими факторами, щяо спонукають викладачів займатися своєю роботою чи організацією.

Висновки: У цъьому дослідженні особлива увага приділялася кращому плануванню роботи, щуоб заохочувати викладачів та максимально використати їхні навички та компетениії. Зосередження уваги на мотиваџійних факторах також покращило якість роботи та баланс між роботою та особистим життям.
\end{abstract}

Ключові слова: залученість викладача, особистісні характеристики, організаційне середовище.

\footnotetext{
Аннотация

Введение: В исследовании рассматриваются личностные характеристики и организационная среда как предикторы вовлеченности. Вовлеченность преподавателя включает в себя вовлеченность в работу, вовлеченность в организацию и вовлечённость в исследование как конструкт второго порядка.

Цель: Исследовать различные зависимые и независимые переменные, влияющие на построение вовлеченности преподавателей и их предикторы; разработать инструмент для измерения уровня вовлеченности преподавателей; спрогнозировать факторы, способствующие вовлечению преподавателей, чтобы дать возможность руководству учебного заведения связать работу и организационную среду.
} 
Материалы и Методы: Исследование направлено на разработку инструментария для измерения уровня вовлеченности преподавателей. Компоненты инструментария созданы на основе мета-анализа литературы. Это исследование проводилось в трех учебных заведениях, а образиы отобраны методом вероятностной выборки. Для проверки адекватности выборки проведен тест КМО. Факторь изучались с помощью исследовательского факторного анализа, а прогнозирующие факторы подвергались линейной регрессии.

Результаты: Это исследование вовлеченности преподавателей показало, что оплата, льготы, объективность, карьерный рост и межличностные отношения являются гигиеническими факторами для Индии. Тем не менее, трудовая этика и содержание работы являются мотивируюшими факторами, побуждающими преподавателей заниматься своей работой или организаџией.

Выводы: В этом исследовании особое внимание уделялось лучшему планированию работы, чтобы поошрять преподавателей и максимально использовать их навыки и компетенции. Сосредоточение внимания на мотивационных факторах также улучшило качество работы и баланс между работой и личной жизнью.

Ключевые слова: вовлеченность преподавателя, личностные характеристики, организационная среда.

The electronic version of this article is complete. It can be found online in the IJES Archive https://ijes.world/en/archive and in the KRPOCH Publishing Repository https://ekrpoch.culturehealth.org/handle/lib/58 